(The 3rd ICBS-2013)

\title{
ASSESSMENT OF SURFACE WATER QUALITY FOR IRRIGATION PURPOSES IN JEMBER DISTRICT, INDONESIA
}

\author{
Retno Wimbaningrum ${ }^{1}$, Endang Arisoesilaningsih"2), Catur Retnaningdyah²), \\ Serafinah Indriyani²) \\ 1)Dept. of Biology, Faculty of MIPA, University of Jember; \\ 2) Dept. of Biology, Faculty of MIPA, University of Brawijaya \\ wimbaningrumsubagio@gmail.com
}

\begin{abstract}
Irrigated agriculture is dependent on an adequate water supply of usable quality. The analysis of physicochemical parameters of surface water inJember District was done for the criteria of irrigation water quality. Surface water comprises spring water, falls, rivers, and tertiary irrigation channels. For this purpose, three sectors or locations were chosen to take twenty seven water samples in the summer season (September to October, 2013). DO, electrical conductivity $\left(\mathrm{EC}_{\mathrm{w}}\right), \mathrm{pH}$, and water temperature values were measured directly in the field, while analyses of nitrate $\left(\mathrm{NH}_{3}-\mathrm{N}\right)$, orthophosphate, total dissolved solids (TDS), and bicarbonate $\left(\mathrm{HCO}_{3}{ }^{-}\right)$was conducted in a laboratory. The results indicated that $\mathrm{EC}_{\mathrm{w}}, \mathrm{TDS}, \mathrm{pH}$, water temperature, $\mathrm{NH}_{3}-\mathrm{N}$, and orthophosphate were under the limits set out by the Rules of the Republic of Indonesia Government (PP RI) No. 82, 2001, for water quality standard and FAO for irrigation water quality standard. Thus, the surface water of Jember District was considered to be suitable for irrigation at the sampled location.
\end{abstract}

Key words: Surface water quality; irrigation; physico-chemical parameter; Jember District.

\section{INTRODUCTION}

Water in agricultural activities is an important component that is supplied by a network of irrigation channels. Rivers, lakes, and spring water are sources of irrigation water that are facing pollution problems.Agricultural water sources may be of poor quality because of natural causes, contamination, or both (Ayers and Westcot, 1985). Indonesian rivers are polluted due to the discharge of untreated sewage and industrial effluents. The poor water quality of rivers and spring water has an effect on irrigation water quality. In the last century, surface water resources have been polluted to such levels that they could no longer be used in agricultural irrigation (Simsek and Gunduz, 2007).

The quality of irrigation water directly influences the quality of the soil and the crops grown on this soil. Poor irrigation water quality has a negative effect oncrop productivity, crop product quality, and public health of consumers and the farmerswho come in direct contact with theirrigation water (Qadir et al., 2007; Listkas et al., 2010; Muthana, 2011). Problems originating from irrigation water quality can be categorized intofour groups: (1) salinity hazards, (2) infiltration and permeability problems, (3) specific ion toxicity, and (4) miscellaneous problems (Simsek and Gunduz, 2007).

Agricultural activities in Jember District are supported by irrigation water that is supplied by springs. One of the springs lies in the conservation area of Meru Betiri National Park that is Watu Gembuk. Tancak Spring lies in the wild area that is located far from urban areas and industrial activities. We have the assumption thatthis spring's water quality is good because of its location in the conservation area and fardistance from urban areas. Until now, 
we could not find information on the water quality of that spring especially quality for irrigation purposes. According to the above mention, it is of importance to assess the water quality of the surface water in Jember District,particularly for irrigation purposes.

\section{MATERIALS AND METHODS}

\section{Study area and sampling sites}

This study was performed at three stations: Watu Gembuk Spring, Tancak Falls, and Jompo River. Each station was divided into three sub-stations. Watu Gembuk Spring was divided into Watu Gembuk Spring,Watu Gembuk Stream, and a tertiary irrigation channel in the Block of Aren. Two of the first lie in the conservation area of Sanenrejo Resort of Meru Betiri National Park that water source of the tertiaryirrigation channelin the Block of Aren. These sub-stationsare located between South latitudes $08^{\circ} 23^{\prime} 33.2^{\prime \prime}$ to $08^{\circ} 22^{\prime} 04.7^{\prime \prime}$ and East longitudes $113^{\circ} 47^{\prime} 32.8^{\prime \prime}$ to $113^{\circ} 47^{\prime} 14.2^{\prime \prime}$. Tancal Falls was divided into Tancak Falls, Gunung Pasang River, and a tertiary irrigation channel in Payung village, locatedbetween South latitudes $08^{\circ} 03^{\prime} 54.0^{\prime \prime}$ to $08^{\circ} 07^{\prime} 12.6^{\prime \prime}$ and East longitudes $113^{\circ} 37^{\prime} 6.3^{\prime \prime}$ to $113^{\circ} 37^{\prime} 12.8^{\prime \prime}$. Jompo River sampling station was divided into a part of Jompo river as the first sub-station that is located near spring water, Jompo River as the second sub-station, and a tertiary irrigation channel in Slawu village as the third sub-station whosewater flows from Jompo River. The third group of sub-stations lies between South latitudes $08^{\circ} 08^{\prime} 14.8^{\prime \prime}$ to $08^{\circ} 09^{\prime} 28.0^{\prime \prime}$ and East longitudes $113^{\circ} 40^{\prime} 52.7^{\prime \prime}$ to $113^{\circ} 41^{\prime} 22.6^{\prime \prime}$.

\section{Sampling and measuring of water quality parameters}

The sampling and measuring of water quality parameters were done at three sampling points ineach sub-station during the summer season of September to October, 2012. Electrical conductivity $\left(\mathrm{EC}_{\mathrm{w}}\right)$, water temperature, and $\mathrm{pH}$ were directly measured ateach sampling point using a portable EC-meter, $\mathrm{pH}$-meter, and thermometer. Water samples were collected at each sampling point using PVC bottles. The water samples were kept at $4^{\circ} \mathrm{C}$ in a cool box until their analyses in the laboratory of nitrate, orthophosphate, bicarbonate, and total dissolved solids (TDS). The analyses weredone using the Brusin method for nitrate, spectrophotometry method for orthophosphate, titrimetry method for bicarbonate, and gravimetry method for TDS (Clesceri et al., 1998). The physico-chemical data were tabulated and analyzed using one sample t test to compare with data set out by the Rules of the Republic of IndonesiaGovernment (PP RI) No. 82, 2001, for water quality standard especially class 2, class 3 , and class 4 for plant watering and FAO for irrigation water quality standard using the program SPSS16.0 for Windows.

\section{RESULTS AND DISCUSSION}

The values of temperature, $\mathrm{pH}, \mathrm{EC}_{\mathrm{w}}, \mathrm{NO}_{3}-\mathrm{N}$, TDS, orthophosphate, and $\mathrm{HCO}_{3}$-in the springs, falls, rivers, and irrigation channels of the study area are shown in Table 1 . The values represent the mean and the range of nine sampling points at each station. The values of $\mathrm{pH}, \mathrm{EC}_{\mathrm{w}}, \mathrm{NO}_{3}-\mathrm{N}, \mathrm{TDS}$, and $\mathrm{HCO}_{3}$ are within the permissible limit for irrigated agriculture according to the Rules of the Republic of IndonesiaGovernment (PP RI) No. 82, 2001, of water quality standard especially class 2 , class 3 , and class 4 for watering plant and 
according to Food and Agriculture Organization (FAO) of irrigation water quality standard (Ayers and Westcot, 1985).

The $\mathrm{pH}$ valuesof the surface water of the study area rangedfrom7.2 to 7.9. This value is within the permissible limit for irrigated agriculture according toPP RI No. 82, 2001, (5 to 9) and FAO (6.5 to 8.4). The $\mathrm{pH}$ values in Jompo River were lower compared with two other stations (Table 1) That condition due to the antrophogenic acidity originated by source such as generated organic substances. Plants can beaffected abnormally if the $\mathrm{pH}$ value is not suitable (Ayers and Westcot, 1985).

One of the problems originating from irrigation water quality is salinity hazard. This problem was assessed by measuring $\mathrm{EC}_{\mathrm{w}}$ and TDS. The values of these parameters indicate the availability of water to plants. The high value ofEC $C_{w}$ and TDS in the irrigation water resultedin increased salinity of the soil. If soil salinity increases, usable plant water in the soil solution decreases dramatically. Plants cannot compete with ions in the soil solution for water because the plants can only transpire pure water. The plants wilt because the roots are unable to absorb the water. High concentration of salt in the soil can result in a "physiological" drought condition.

Table 1. Physico-chemical qualities of surface water in Jember District

\begin{tabular}{|c|c|c|c|c|c|c|c|c|c|}
\hline \multirow[t]{2}{*}{$\begin{array}{l}\text { Physico- } \\
\text { chemical } \\
\text { parameters }\end{array}$} & \multicolumn{3}{|c|}{$\begin{array}{l}\text { Watu Gembuk Spring } \\
\text { (Sanenrejo Resort, } \\
\text { MerubetiriNational Park) }\end{array}$} & \multicolumn{3}{|c|}{$\begin{array}{c}\text { Tancak Spring (Suci and } \\
\text { Payung Village) }\end{array}$} & \multicolumn{3}{|c|}{$\begin{array}{c}\text { Jompo River } \\
\text { (Slawu Village) }\end{array}$} \\
\hline & Range & Mean & Sd & Range & Mean & Sd & Range & Mean & Sd \\
\hline Temp. $\left({ }^{\circ} \mathrm{C}\right)$ & $22.7-28.8$ & 25.2 & 2.6 & $18-26.4$ & 22.6 & 3.3 & $26.6-31.9$ & 30.3 & 1.9 \\
\hline $\mathrm{pH}$ & $7.2-7.9$ & 7.7 & 0.3 & 7.2-7.6 & 7.4 & 0.2 & $6.9-7.5$ & 7.3 & 0.2 \\
\hline $\mathrm{EC}_{\mathrm{w}}(\mathrm{dS} / \mathrm{m})$ & $0.2-0.3$ & 0.2 & 0.1 & $0.05-0.06$ & 0.06 & 0.01 & $0.10-0.15$ & 0.13 & 0.02 \\
\hline $\mathrm{NO}_{3}-\mathrm{N}(\mathrm{mg} / \mathrm{l})$ & $0.12-0.47$ & 0.24 & 0.1 & $0.08-0.39$ & 0.23 & 0.1 & $0.89-1.63$ & 1.14 & 0.23 \\
\hline Orthop.(mg/l) & $0.04-0.08$ & 0.52 & 0.2 & $0.02-0.05$ & 0.03 & 0.09 & $0.06-0.07$ & 0.07 & 0.01 \\
\hline $\mathrm{HCO}_{3}{ }^{-}(\mathrm{meq} / \mathrm{l})$ & $2.23-2.83$ & 2.4 & 0.2 & $0.81-1.21$ & 0.97 & 0.1 & $1.42-1.82$ & 1.59 & 0.16 \\
\hline TDS (mg/l) & $80-380$ & 181.44 & 115 & $220-380$ & 330 & 54 & $320-580$ & 431 & 88.8 \\
\hline
\end{tabular}

Less water is available to plants, even though the soil may appear wet (Joshi et al., 2009; Shahinasi and Kashuta, 2008). According to PP RI No. 82, 2001, the TDS value is within the permissible limit for irrigated agriculture $(<1000 \mathrm{mg} / \mathrm{l}$ for class 2 and 3 , and $<2000$ $\mathrm{mg} / \mathrm{l}$ for class 4$)$. According to $\mathrm{FAO}$, the $\mathrm{EC}_{\mathrm{w}}$ value of surface water in Jember District falls under no degree of restriction on use because the value ranged from 0.05 to $0.3 \mathrm{dS} / \mathrm{m}$ (Table 1). The TDS value rangedfrom 80 to $580 \mathrm{mg} / \mathrm{l}$ (Table 1), falling under two categories of water quality for irrigation according to $\mathrm{FAO}$. The categories are no degree of restriction on use $(<450 \mathrm{mg} / \mathrm{l})$ and slight to moderate degree of restriction on use $(450-2000 \mathrm{mg} / \mathrm{l})$. The source of dissolved solids in water is natural as minerals in soil and anthrophogenic as agrochemicals (Kundu, 2012). The source of dissolved solids in the water of Watu Gembuk Spring, Watu Gembuk Stream, Tancak Falls, and Gunung Pasang River are natural as minerals in soil. The locations of the four sub-stations are far from urban and activities areas, representative of the protected area in Jember District. Anthrophogenic agrochemicals are the source of dissolved solids in the water of Jompo River and three irrigation channels because the sub-stations are close to agricultural and urban areas. 
$\mathrm{HCO}_{3}{ }^{-}$contents varied from 0.81 to $2.83 \mathrm{meq} / \mathrm{l}$ (Table 1). That value of bicarbonate indicates low cations and anions in the water of the study area. According to FAO, the water quality of the surface water in Jember District falls under slight to moderate degree of restriction on use. Bicarbonate, calcium, and sulphate present in irrigation water causea white coloration of fruits and leaves, which decreases the quality of agricultural products (Ayers and Westcot, 1985).

The range value of $\mathrm{NO}_{3}-\mathrm{Nin}$ the water surface of the study area was $0.08-1.63 \mathrm{mg} / \mathrm{l}$. The $\mathrm{NO}_{3}-\mathrm{N}$ concentration in the Jompo River station was higher $(0.89-1.63 \mathrm{mg} / \mathrm{l})$ compared with two other stations (Watu Gembuk Spring station: 0.12-0.47 and Tancak Falls station: 0.080.39 ) (Table 1). The $\mathrm{NO}_{3}-\mathrm{N}$ concentration in the Jompo River station is supplied from point and non-point sources. The location of the Jompo River station is close to agricultural and activities areas that contribute to enriched nitrogen. This nitrogen is considered as input to the crops in the directly available form of $\mathrm{NO}_{3}-\mathrm{N}$. The domestic wastes also contribute to the increased $\mathrm{NO}_{3}-\mathrm{N}$ concentration of Jompo River station. According to $\mathrm{FAO}$, the $\mathrm{NO}_{3}-\mathrm{N}$ value is within the permissible limit for irrigated agriculture and falls under slight to moderate degree of restriction on use $(<5 \mathrm{mg} / \mathrm{l})$. The problem originating from nitrate is fast plant vegetative growth, delay of plants'reproductive phase, and the soil in full waters.

Phosphate concentration rangedfrom 0.02 to $0.08 \mathrm{mg} / \mathrm{l}$ (Table 1). According to PP RI No. 82,2001 , the $\mathrm{NO}_{3}-\mathrm{N}$ value is within the permissible limit for irrigated agriculture $(0.2-5$ $\mathrm{mg} / \mathrm{ll}$. Phosphate in the water samples was present when irrigation is intensive in the rice fields, which results in higher surface runoff and water losses to the streams, rivers, and irrigation channels.

\section{CONCLUSION}

The values of $\mathrm{EC}_{\mathrm{w}}, \mathrm{TDS}, \mathrm{pH}$, water temperature, $\mathrm{NO}_{3}-\mathrm{N}, \mathrm{HCO}_{3}{ }_{3}$, and orthophosphate of the surface water in Jember District were within the limits set out by the Rules of the Republic of Indonesia Government (PP RI) No. 82, 2001, for water quality standard and FAO for irrigation water quality standard. Thus, the surface water of Jember District was considered suitable for irrigated agriculture at the sampled location.

\section{REFERENCES}

Ayers, R.S., and D.W. Westcot. 1985. Water Quality for Agriculture, FAO Irrigation and Drainage. Paper No.(29), Rev.(1), U.N. Food and Agriculture Organitation, Rome.

Clesceri, L.S., A.E. Greenberg, and A.D. Eaton. 1998. Standard Methods for the Examination of Water and Waste Water. $20^{\text {th }}$ Ed., Washington

Joshi, D.M., A. Kumar, and N. Agrawal. 2009. Assessment of the Irrigation Water Quality of River Ganga In Haridwar District. Rasayan Journal Chemistry Vol. 2, No. 2:285-292

Kundu, S. 2012. Assessment of Surface Water Quality for Drinking and Irrigation Purposes: A Case Study of Ghaggar River System Surface Waters. Bulletin of Environment, Pharmacology \& Life Sciences Vol. 1, Issue 2:1-1

Listkas, V.D., V.G. Aschonitis, and V.Z. Antonopulos. 2010. Water Quality in irrigation and Drainage Networks of Thessalonski Plain in Greece Related to Land Use, Water Management, and Agroecosystem Protection. Environ. Monit. Assess. 163:347-359 
Muthanna, M.N. 2011. Quality Assessment of Tigris River by Using Water Quality Index for Irrigation Purpose. European Journal of Scientific Research 57:15-28

Qadir, M., D. Wichelns, L. Raschid-Sally, P.S. Minhas, P. Drechsel, A. Bahri, and P. McCornich. 2007. Agricultural Use of Marginal-Quality Water Opportunities and Challenges. IWMI Part 4:225-226

Shahinasi, E., and V. Kashuta. 2008. Irrigation water quality and its effects upon soil. BALWOIS 2008-Ohrid, Republic of Macedonia-27:1-6

Simsek, C., and O. Gunduz. 2007. IWQ Index:A GIS-Integrated Technique to Assess Irrigation Water Quality. Journal of Environmental Monitoring and Assessment 128:277-300. 